\title{
Fracturing Debate? A Review of Research on Media Coverage of "Fracking"
}

\author{
Julian Matthews* and Anders Hansen \\ School of Media, Communication and Sociology, University of Leicester, Leicester, United Kingdom
}

Hydraulic fracturing is an energy extraction process that is increasingly attracting controversy. This article seeks to outline how the media report hydraulic fracturing (or "fracking"), and to explore its place within the reporting of energy concerns generally. To this end, it draws on an environmental communication perspective to understand the media reporting of the issue and the processes that shape it. This review reveals that media reporting of fracking is partitioned broadly according to discussions of the economic benefits or the environmental risks associated with the process. Further, these observed patterns in the reporting appear to mirror the recognized claims made about the issue, and the influence from protests and online media alongside national polity on energy production and security. While there is evidence that the practices of journalists and the geographic, economic and political contexts of their news production environments shape the amounts and the types of news reporting, the publics' perceptions appear, somewhat knowledgeable, but largely ambivalent or undecided on the issue at present. Therefore, it is argued that future research must continue to examine the reporting of hydraulic fracturing, its context, production, and its wider reception to develop our understanding of the role of the media in national conversations on fracking, energy, and the environment.

Florida Juliet Pinto,

Andrea Olive,

University of Toronto, Canada nal University, United States

*Correspondence: Julian Matthews jpm29@/eicester.ac.uk

Specialty section: This article was submitted to

Science and Environmental Communication,

a section of the journal

Frontiers in Communication

Received: 28 March 2018

Accepted: 29 August 2018

Published: 21 September 2018

Citation:

Matthews J and Hansen A (2018)

Fracturing Debate? A Review of Research on Media Coverage of

Keywords: fracking, controversy, energy, environmental communication, journalism, politicization, mediation, public understanding

\section{INTRODUCTION}

Drawing on an emerging body of environmental communication research on the reporting of energy issues, this paper discusses insights gained from research emerging primarily since the early 2000s into media coverage of the form of energy extraction known as hydraulic fracturing. "Fracking" as it is often termed, presents an important case study in this regard. The extraction of shale gas and oil reserves through a procedure to fracture rock has gathered momentum in the present century and its merits have become a subject of debate and controversy (Mazur, 2016). At the same time, the implementation of the process has emerged during national discussions of energy use, energy sustainability, and the impacts of climate change (Philo and Happer, 2013). Against this context, its uptake has often been justified as a partial solution to issues concerning the depletion of national energy resources, decreased production, reliance on energy imports, and appropriate transitions to low carbon futures by related business interests and governments that are supportive of the technology (Jaspal and Nerlich, 2014). Similarly, the impact of the process of hydraulic fracturing on the natural environment has stimulated concerns over the use of the 
technology and "energy justice" by environmental interest groups (Fuller and McCauley, 2016) and has evoked protest and challenge from affected communities (Mercado et al., 2014) alongside those likely to be so in the future.

Hence, we can explore the complex definitional activities over the fracking issue using emerging insights from an environmental communication perspective. This approach recognizes the relationship between the media and the outcomes of a wider politicization process. "Politicization" is used here to explain a general process whereby sets of stakeholders act, and interact, to define and voice claims about fracking as an issue, including in this case: (i) politicians (ii) industry, (iii) interest groups and (iv) local protesters (Hansen, 2011). This meaning differs from a more specific use of politicization found elsewhere that recognizes efforts to problematise issues (such as is observed in the activities of the countermovement of fossil fuel interests operating in the climate change issue-see Pepermans and Maeseele, 2016). These facets of the politicization of fracking provide a context to understand the medias interest in, and reporting of, the issue. Still, the institutionally based activities of journalism are important also. Collectively these make up a process of mediation and the specifics of which remain a key research interest for media scholars (see Livingstone, 2009). In practice, journalists mediate (i.e., select and shape) their coverage of fracking while working within specific organizations and acting according to a 24-h news cycle, news routines and accepted professional values (Anderson, 2014). Combining the study of the processes of politicization and mediation takes us a considerable way on the journey to explaining coverage of these types of issue (Matthews, 2016). Nevertheless, there is a need to engage also with real national politics and national media. Charting national political discussions of fracking and their reporting in national media will likely reveal the degree to which the issue is subject to "domestication" (Gurevitch et al., 1991; Djerf-Pierre et al., 2015). This will also provide a base on which to explore the differences in national media conversations on the issue and the factors that shape them.

Our point of departure for the argument and the review presented here is in the media and communications literature on news and journalism with a focus on the emerging and increasingly distinctive field of environmental communication. Within this broader context, our specific focus in this article is on mediated communication of energy generally, and on fracking in particular. Drawing from the long-established history of research on news and other mediated communication about energy and energy-related issues, and drawing from major state-of-the-art overviews of environment and communication (Hansen and Cox, 2015; Nisbet, 2018; Pezzullo and Cox, 2018), and on key book publications referencing media/communication and energy (notably Mazur, 2013; Philo and Happer, 2013; Schneider et al., 2016; Takach, 2016) our strategy for identifying relevant studies revolves around key-word and citation searches in the Web of Science database. We have conducted searches in Web of Science in several rounds since 2015 and most recently in March of 2018. Our searches revolved around a two-pronged approach: first, identifying articles mentioning media/communications terms (news, journalism, media, communication, etc.) AND fracking and fracking related terms [frack(ing), hydraulic fracturing, shale-gas, etc.]; and second, where titles and/or abstracts indicated potential relevance, we used the Web of Science citation listing, to pursue subsequent articles that cite the articles initially identified through key-word searching. Our emphasis is on the peer-reviewed research literature on news, news sources, journalistic practices, and mediated communication about fracking, and we have thus not included (except where this touches specifically on media and news roles) in this review publications primarily about public opinion or public perception (comprehensive reviews of these areas are e.g., Whitmarsh, 2015; Thomas et al., 2017). In addition, we recognize that there are some limitations on what can be accessed from these databases, including the comprehensiveness of indexed journals and the predominance of English language publications contained with these databases.

\section{ENERGY AS AN ENVIRONMENTAL ISSUE}

Media coverage of energy and problems with its extraction often implicitly consider energy as a naturalized resource whose greatest concern is its susceptibility to global trends of supply and demand. These normalized assumptions tend to delimit the discussion of energy as an issue (see Maeseele, 2017). Those issues that become a subject of political discussion or contest (i.e., become politicized) nonetheless are subject often to a move from business-centric reporting to the mainstream. At these times, media scholars suggest that reporting follows developments within political institutions (Hallin, 1985; Bennett, 1990; Shehata and Hopmann, 2012). Similar to other politicized concerns, energy and specifically energy policy emerges as part of the national cycle of political discussion/contest to which journalists' attention is attuned (Curtin and Rhodenbaugh, 2001). More spontaneous than these routinised occurrences however, are the developments that affect citizens and consequently demand political action, such as energy shortages or crises (Cozen et al., 2017). At other times, interest groups and organizations direct the medias' attention to their view of policy reform and related concerns about climate change and sustainability (DeLuca, 2009). Additionally, other catalysts underpin coverage, and these include sizable events and/or disasters involving the transportation or the refining of energy forms (Endres et al., 2016). The widespread pollution or other harmful effects on the environment and its occupants (e.g., oil spills or nuclear accidents) inevitably gain visibility in media reporting (Hannigan, 2014). Academic work recognizes continuities in the media coverage of these episodes and in the activities of stakeholders and journalists that produce it (Bolsen, 2011).

The communication and media reporting of energy issues has long attracted considerable scholarly attention, and is amongst the earliest foci of environmental communication research (Hansen, 2009). In their comprehensive review of energy communication research, Endres et al. (2016) characterize energy communication as a crisis discipline (borrowing (Cox's, 2007), labeling of environmental communication) and note that their review "of communication scholarship on energy 
reveals a history of research that primarily responds to crises, from particular energy crisis events (e.g., Fukushima nuclear disaster 2011) to the more encompassing climate crisis." (Endres et al., 2016: p. 420). To a degree then, the focus and amount of media reporting always reflects the period in which it emerges (see Hansen, 1991; Hannigan, 2014). For example, those environmental problems encountered when extracting energy have the potential to "command attention" and to question the place of technological achievement in the workings of capitalism (Lowe and Morrison, 1984). In reality, though, their reporting tends to follow an individualized and naturalized focus around the occurrence. Oil spills are often talked about in terms of their abnormality as events for instance or according to the individualized blame attributed to the companies or the individuals involved, rather than being situated within oppositional arguments between wider environmental concerns and industrial concerns (Daley and O'Neill, 1991). While these events offer opportunities for green interest groups to comment on any harmful effects from them on the environment (Hansen, 2000), industry speakers often work to control the process to define the event and to manage its discussion in the media by directing journalists' attention to their "updates" and/or their commentaries on "responsibility" and "compensation" (Choi, 2012). Even the risks associated with nuclear power have been mediated in a similar way recently. The wider questioning of nuclear power as an appropriate energy source for instance has often been muted within news coverage that reproduces a fatalistic tone (Gamson and Modigliani, 1989) or focuses on either diminishing risks (Tollefson, 2014) or general issues of safety (Flynn et al., 1988).

Nonetheless, recently media discussion of energy extraction has referenced concerns about climate change, depleting resources (sustainability) and energy security (Djerf-Pierre et al., 2015). A discussion of "green" energy (i.e., alternatives to fossil fuels) develops in this context, for instance. While reporting mentions the goal to reduce the production of carbon dioxide $\left(\mathrm{CO}_{2}\right)$, it often explains these forms of energy production according to technology and growth-led solutions (Davidsen and Graham, 2014). Bio fuel, carbon capture and renewable energy are discussed simply in terms of the economic growth, or the economic benefits, they provide for their home countries (Stephens et al., 2009; Wright and Reid, 2011; FeldpauschParker and Peterson, 2014; Djerf-Pierre et al., 2015). Other energies receive a rebranding in this context. Nuclear energy, for instance, is introduced as "emission free" and "eco-friendly" in the present political climate in some countries (Pralle and Boscarino, 2011), and related media coverage presents the risks of nuclear power as off-set by its economic benefits (Culley et al., 2010; Wang et al., 2014). Accompanying this framing is other discussion of energy and the robustness of the national energy system or what has been termed as countries' "energy security" (Ang et al., 2015).

Analysis of the definitional activities of stakeholders can therefore help to explain the frequency and the character of the reporting of energy issues. These insights sit alongside others into mainstream journalism and the process of mediation. Journalists follow common news work routines and practices. Combined and in operation, these construct the focus of the energy issue as a newsworthy story and apply authorized news voices to define and explain it for their reading publics (Anderson, 2014). Wider factors also influence the reporting activities of different journalists. For instance, where a news organization is located within the media ecology or the journalistic field is important to this process (Benson, 2005; Matthews and Cottle, 2012). Organizations that produce broadsheet or serious journalism provide more space within them for the reporting of, and the commenting on, (energy) issues generally than those organizations that produce popular news journalism (Chapman et al., 1997; Matthews, 2016). Media located within particular geographic regions, where energy issues are situated or experienced acutely, will offer more coverage to them than will be given to such issues within national media (Wakefield and Elliott, 2003). How organizations are positioned politically can similarly affect the selection and the shaping of energy issues for the news agenda (Carvalho and Burgess, 2005). As is observed similarly in the reporting of climate change, those media organizations that are sympathetic to the political right and its framing of the ideas of freedom, individualism and economic growth subsequently report energy issues in ways particular to these ideas. Such stories contrast with those produced by newspapers positioned centrally or to the left of the political center ground (Jaspal and Nerlich, 2014).

\section{FRACKING}

Does the reporting of hydraulic fracturing follow the insights of this research? We need to engage briefly with the recent policy on, and reporting history of, this issue to begin to answer this question. A policy to use hydraulic fracturing to supplement other national energy extraction originated in the US and, for a long time, the policy and its inscribed idea of the "right to frack" remained relatively uncontroversial. In the media and until fairly recently, the topic of fracking activity featured largely in a business style of reporting where it was discussed as part of an accepted energy policy. This situation changed in 2010 however with the release of a popular anti-fracking documentary, Gasland. The documentary brought to light a growing US regional contest of, and protest over, hydraulic fracturing and it gathered together and publicized various environmental arguments against the practice. The spread of the documentary through views on Youtube helped further to build the controversy over the fracking process. A developing media coverage followed the growing controversy, and this was curtailed only when the medias' attention was directed to the dramatic events of an oil leak from the BP oil extraction rig in southern US waters (Mazur, 2016). Outside of the mainstream media and its reactions, the release of Gasland stimulated an increase in the number of internet searches for the issue, greater social media chatter and numbers of other Youtube videos (Jaspal et al., 2014b) and it even precipitated "anti-fracking mobilization" argues (Vasi et al., 2015). From this time onwards, research has observed growing protests over the issue (Hopke, 2016) and a subsequent media reaction on this developing situation. Journalists, it is noted, 
have reported on the stakeholder positions in the controversy including those expressed by national governments, politicians, business and interest, and protest groups.

While national contexts and associated public discourse dynamics regarding fracking vary considerably, a picture is beginning to emerge from the growing body of research that shows public and mediated communication on fracking as being very much in flux. Thus, there is evidence from the comparatively small but growing body of research on this topic in the UK that political and discourse coalitions, frames, and public opinion regarding fracking are frequently changing in response to not just changing economic and policy contexts, but interestingly also in response to the strategic media and communication practices of key stakeholders in the debate. In her insightful analysis of "discourse dynamics in UK fracking debates" during two periods of intense news coverage in 2013-14, Bomberg (2017: p. 72) argues that the greater discourse success, demonstrated by her study, of the anti-shale coalition in the UK is due to two reasons: "firstly, because the pro-shale coalition lacks trustworthy messengers; secondly, because shale opponents have successfully expanded the debate beyond economic or environmental concerns to include potent issues of local power and democracy." The emerging strength of anti-fracking oppositional voices in public debate is also demonstrated by Neil et al.'s (2018: p. 182) comprehensive agenda-setting study, which concludes that anti-fracking advocacy groups were more successful in influencing news media content than other key stakeholders, notably government and industry/business, and additionally provides evidence for "the growing influence of digital information subsidies as an effective tool for agendabuilding strategies.”

\section{REPORTING}

Studies of the reporting of fracking confirm that a context of contest informs the news writing about it. The analyzed reporting describes the hydraulic fracturing process as either producing economic benefits or environmental risks, for instance. Mercado et al. (2014) recognize this pattern of coverage as emerging in the US and in the UK over a similar time. Journalists who engage with the issue as an economic "good," outline in their stories the "benefits" of fracking for regional investment, job creation and, for the US regions specifically, the benefits of less dependence on the US state for their energy supply and fracking as a way to secure their financial futures (Bigl, 2017). Complementing the media discussion of economic benefit is journalists' reporting of environmental concerns with the fracking process (Blair et al., 2015). Introduced here are problems over water pollution and the consequent dangers that the aforementioned pollution poses for health (Habib and Hinojosa, 2016). Whereas, media coverage reproduces discussion on the impact of the process on water quality generally, its reporting of the benefits and the risks of hydraulic fracturing appears to vary somewhat according to the geographical contexts of journalists' news organizations (Evensen et al., 2014).
While the media discussion of fracking focuses on its potential dangers, reporting is rarely extended to include any commentary on the actual social impacts of the process (ibid.). Tracing even short-term developments in its reporting uncovers a change in tone from reported optimism to skepticism (Jaspal and Nerlich, 2014). Examining the UK coverage, (Jaspal and Nerlich, 2014) recognized journalists' efforts to challenge claims made about the risks and the dangers within the fracking process, only for them to later "reconstruct" these environmental concerns in their reporting. Therefore "(potential) threats," these authors suggest, play an important role in the mediated process of defending and contesting fracking activity. As part of the process, the technology of hydraulic fracturing, they stress, becomes a focus for the reproduced positive and negative rhetoric.

In addition to discussing the technology of fracking, the media reproduce particular understandings of agriculture and the rural landscape associated with it. Against broader discourses of risk and refusal over the process of hydraulic fracturing, journalists introduce in their reporting, Sneegas (2016) suggests, prominent representations of farmers as important actors in the rural environment in which fracking activity occurs. Farmers appear as (i) landowners, (ii) individuals struggling economically and as (iii) environmental stewards across the analyzed coverage. As coverage changes however, it mobilizes certain constructions of the relationship between agriculture, rural actors and fracking activity while obscuring others. More widely, the description of the issue appears to be compartmentalized in this reporting for the most part. Irrespective of the witnessed changes in direction of its discussion, reporting tends to focus attention either on stories of fracking and the economy or those of fracking and the environment, but rarely do its stories include both simultaneously (Olive, 2016). Hence, it is reasonable to suggest that this reporting is being formed in response to the contest between the definitions of the hydraulic fracturing process. Looming large within this context is the role of the nation and of national politics.

The national context appears to play some role in producing the observed patterns found in the media reporting of fracking and in shaping any differences (Teräväinen, 2014). Countries with national economies dependent on carbon intensive industries and products generate, it is observed, more reporting of domestic debate and discussion over policies designed to address the use of fossil fuels than do other countries (Schmidt et al., 2013). Actual or proposed fracking activity for example is being reported in context of these wider national discussions of energy use, sustainability and the impact of climate change (Philo and Happer, 2013) and the national energy policy and priorities that follow from them (Djerf-Pierre et al., 2015). At present, we can note there are differences in the responses to fracking within countries across Europe. Some countries have either commenced fracking activity or have pursued it as a potential viable energy option (e.g., UK, Netherlands, Poland, Romania, and Ireland- see Neslen, 2016). Elsewhere, there are ongoing discussions about the issue within countries that sanction fracking generally (e.g., USA) with the consequence of some US states now placing moratoriums or bans on the activity (e.g., the recent decision to 
reverse policy and to ban fracking in the State of Maryland-see Wiggins and Hicks, 2017).

Hence, political elite speeches on, and reactions to, the issue transmit these concerns to the media. In response, news journalists index them as part of their reporting (Bennett, 1990). Therein commentaries serve to construct discursive boundaries around the issue and the national conversation on this technology in reporting (Olive and Delshad, 2017) and in turn these inform what reporting excludes, such as the discussion of issues of aboriginal politics, earthquakes and climate change in the Canadian case (Olive, 2016). In addition, the place of fracking in the wider discussion about sustainability and carbon mitigation generates observable discussion, debate and conflict. In such instances, journalists focus their interest on the drama of these conflicts and make efforts in their writing to balance the conflicting voices within them (see Boykoff and Boykoff, 2007). The reporting that follows traces arguments over the benefits and the risks of fracking defined by stakeholders in the carbonbased industries and those from the environmental lobby. Further, the national geographical dimension that underpins these domesticated media discussions often supersedes the use of other reporting frameworks on energy issues (Djerf-Pierre et al., 2015). Jaspal et al's (2014a) discussion of the press in Poland is insightful in this regard. This study recognizes how national energy policy (concerned with national "energy security" in this case) helps to polarize the media discussion of fracking activity in a "positive" direction. As part of the process, the media coverage constructs criticism of the fracking process as counter normative and "un-Polish" (Jaspal et al., 2014a). Moreover, outspoken political support for the process is often included as part of the national media reporting in countries where their governments have included fracking as part of their energy strategy (Matthews and Hansen, 2016), while the issue is seen to be increasingly divisive elsewhere (e.g., Ireland, see Steger and Drehobl, 2018; USA, see Wiggins and Hicks, 2017).

\section{STAKEHOLDERS}

In addition to the efforts of politicians to communicate energy policy to journalists, it is the activities of other stakeholders that also help to inform how the fracking issue appears in the media. By looking specifically at shareholders' claims making on the issue, studies allow us to observe the connections that exist between stakeholders' comments and the themes found in the related media reporting. According to Metze and Dodge (2016), two sets of discourse coalitions emerge within the claims making process on fracking. Compared, these coalitions construct the process to extract shale gas as either "an environmental threat" or "an economic opportunity." What is more, a detailed analysis of these claims reveals efforts on the part of their stakeholders to highlight particular aspects of benefit or risk. Much discussion focuses on the outcomes of fracking activity as connected to local property values, economic benefits and health effects, for instance.

Still, a significant number of claims limit their focus to environmental concerns over hydraulic fracturing activity
(Metze, 2014). Detailed within these anti-fracking claims are the environmental impacts and the risks associated with the extraction process (Buttny and Feldpausch-Parker, 2016). Claims suggest that the extraction of shale gas and oil, despite industry claims to the contrary, is polluting in an equal measure to the other processes that are used in the extraction of fossil fuels. Similarly, these stakeholders voice an unease in response to those who campaign, are involved in, and support the extraction process. They question the practice to trust these individuals and groups and at the same time cast general skepticism on the intentions of, and comments made by, the fossil fuel industry on the hydraulic fracturing process generally (Cotton et al., 2014). Communicated additionally is a requirement to protect areas from scale gas extraction as part of the repeated calls that stakeholders make for new legislation, in the public interest, to restrict existing and potential extraction (Cotton, 2015).

At the same time, contrasting claims devise a pro-fossil fuel narrative that bolsters the importance of the technology of hydraulic fracturing. Sustained efforts are made to counter the existing "negative" perceptions of its extraction process. These pro-fracking stakeholder narratives explain the natural gas extraction process as "morally acceptable" and one that is clean when contrasted to the traditionally "dirty and damaging" oil extraction process (Chen and Gunster, 2016). Likewise, claims emphasize the "positive" position of hydraulic fracturing in the energy policies of many countries. Shale gas is introduced as a potential "bridging fuel" for many countries that will sustain their economic growth and their energy security in the short term (Cotton, 2015) and will facilitate their energy transitions to a low carbon energy system in the medium term (Cotton et al., 2014). Highlighted also are the decisions to embrace fracking that have been taken by many governments on the basis of their assessments of the potential risks and the benefits of the process. With these points made, pro-fracking claims move purposefully to invite citizens and local communities to partake in an entrepreneurial discourse on the potential of fracking as producing energy independence (Finewood and Stroup, 2012). Stressing the social, the economic, and importantly the individual outcomes (benefits) from the process (Hudgins and Poole, 2014) these pro-fracking claims seek to direct public thoughts away from those environmental risks with hydraulic fracturing process that are discussed by others (Chen and Gunster, 2016: p. 315). In sum, pro-fracking claims often construct selective histories and futures (Rich, 2016) and connect fracking to ideas of patriotism and scientific reason within these constructions (Matz and Renfrew, 2015) to justify the fracking process and to gain visibility for its "benefits" within news reporting.

Assessments on the relative success of pro-fracking and antifracking discourses are relatively rare in the academic literature. The recent work of Bomberg (2017) is a unique example in this respect. Providing a systematic examination of press reports, websites and public documents in the UK, it uncovers the storylines that shape the "understanding, meaning and debates" (2017: p. 72) found in both "pro-shale" and "anti-shale" discourse coalitions. After assessing their relative resonance and power, the study concludes that anti-shale coalitions have benefitted 
from directing their focus on the issues of local politics. Additionally, they have gained from an observed inability of the pro-shale coalition to put forward "trustworthy messengers" who maintain attention on the potential economic benefits of fracking activity.

\section{MEDIATION}

From what has been discussed thus far, we can recognize that reporting constructs a discussion of fracking that includes the views of different interested stakeholder groups. Broadly, it is stakeholders' positions that bolster the developing politicization of the issue and, in turn, attract media reporting, although recently some suggest that there is emerging evidence of a reciprocal relationship between the reporting of fracking and the decision making of policy makers (e.g., Schirrmeister, 2014). Notwithstanding the suggested relationship between the reporting of fracking and the power of stakeholders, many suggest that other processes of mediation equally shape the frequency and the character of the observed reporting. General journalistic routines and practices literally construct the reporting of the fracking issue. Reporting follows the attention that elites give to the fracking issue because news practices proportionally favor the authority and credibility of elite spokespeople and institutions as sources of news (Hedding, 2017). Journalists include the definitions and evaluations made by politicians and business elites in contrast to those of others (e.g., those of green interest groups and individualssee Hansen, 2010) in line with their practices to include voices according to their perceived credibility and the professional values of objectivity and impartiality. But equally the controversy shaped in, and reproduced by documentaries (e.g., Gasland), social media discussion and activism that follows in this case, also plays a part in placing the issue on the news agenda (Vasi et al., 2015). Such activity not only ascribes newsworthiness to the issue for journalists but also assists in their framing of fracking as a "controversial" or a "conflicted" issue. Correspondingly, other general journalistic practices assist in excluding the fracking issue from the news agenda. To appear in the news, fracking stories must, it is argued, be event-led and thus fit within a 24-h cycle of news reporting, demonstrate values of "conflict, emotion or oddity" as well as show a potential to offer the "good pictures" that are required by broadcast and increasingly online reports (Anderson, 2014).

Moreover, there are differences to observe in the outlooks that elite and popular news outlets adopt on an environmental controversy such that of fracking activity in their reporting. Popular news outlets, for example, cover less political issues generally in their agendas and they concede only to do so when an issue is considered to be affecting their readers' lives (Matthews and Brown, 2012; Sjölander and Jönsson, 2012). There are also geographical dimensions that inform the reporting of the fracking issue. Within the news ecology, the national media often follow elite stakeholder commentary and discussions on fracking, whereas regional or local journalism is more likely to chart the impact of this energy issue on their local area (Johnstone and Mando, 2015; Maeseele et al., 2015). In general, local or regional journalism reports on evidence of, or speculation on, local impacts or implications of the issue with greater frequency and intensity as well as provides space for the voices of those who are actually or potentially affected (Anderson and Marhadour, 2007). Their journalists also apply the idea of proximity ("the local") when writing about fracking activists with the consequence of defining them, among others, as either "locals" or "outsiders," it is found (Steger and Drehobl, 2018).

In addition, there is evidence of an overlap between these distinct news agendas, at times. When local or regional journalism reports on a story that then moves to set the national agenda, it appears to retain some of the "inflection" or the newsworthiness (local impact, local voices) that is encoded within it by local journalism (Hansen, 2010). Hence, these local contested issues are observed to be the recipients of a more nuanced treatment in the national news in comparison to other national stories that remain subject to its traditional skew toward elite commentary. Any local contests over fracking take a place in the history of other locally fought environmental issues (e.g., over recycling plants, waste storage, road building, airport expansions etc.-see Rootes, 2013) that have gained national media attention. Like their predecessors, fracking stories hold the potential to focus their reporting on the perspectives of ordinary, local people and their emotional distress and concerns about the disruption or the destruction of their "decent" "way of life" at the hands of large, insensitive, profit-oriented companies (see Cox, 2010; Sjölander and Jönsson, 2012).

Wherever they are located institutionally, journalists use a variety of voices to define issues and solutions, and to adopt positions within stories and therein assumedly remove their personal voice and their influence on what is being reported. Even so, the voices that are included in the news can vary according to the geographic context of the respective news outlets (national, regional, or local) as is noted above, but also vary according to the economic context (public service vs. commercial) and the political context (left, center, right) of news organizations (Anderson and Marhadour, 2007). In terms of the latter, any reproduced voices or positions on issues are often shaped in line with the positioning of the commercial newspaper outlet. Prominent in Jaspal and Nerlich (2014) analysis of the UK commercial media, is an observed division in the positions that newspapers adopt on fracking. Pro-fracking arguments appear in the newspapers that position themselves politically to the right of the center ground. Anti-fracking arguments, it follows, appear most readily in those newspapers that position themselves in the political center ground or to the left of the center ground. For some, this mediation process more than the character of the wider politicization of the issue shapes the reported view of fracking. For others, the discussions of newspaper reporting covered here, offer only a partial picture that overlooks the contribution of broadcast coverage on the topic and that from the online news outlets which continue to spark interest from news scholars (see Boczkowski and Anderson, 2017). At the same time, we should acknowledge that our understanding of the process by which the public 
come to understand, to talk about and to act on the issue of fracking, is as complex as those of its politicization and its mediation.

\section{PUBLICS}

There is a relative dearth of work on the audiences' understanding of the media reporting of hydraulic fracturing (and other energy issues) in comparison to research on its news coverage. Nevertheless, it is reasonable to assume that audiences actively interpret this type of reporting as has been observed in research on audience responses to other issues (Ross and Nightingale, 2003). Reporting has been found to raise awareness of environmental risks and issues among them, for instance (Philo and Happer, 2013; Kristiansen, 2017). At the same time, research suggests that audiences' agendas on the issue will likely follow the stakeholders who influence media reporting, including for example the sustained influence of advocacy groups over that of government and industry on the fracking issue (Neil et al., 2018: p. 202). In their responses to the reporting, audiences are found to share interpretations of the issue and the risks associated with it. But, simultaneously, audiences tend to react differently to images of fracking activity (Krause and Bucy, 2018) and to the coverage according to their characteristics (e.g., gender, age, location) and a range of other factors that influence people's thinking (see Gamson, 1992; Kitzinger, 1998; Boyd, 2017). Recent findings from survey research that focuses on the perception of hydraulic fracturing along UK and US publics is revealing in this regard. Here publics are shown to be unaware of, ambivalent to, or largely undecided on the process of hydraulic fracturing generally (Boudet et al., 2014; Whitmarsh et al., 2015). In detailing respondents' views on this form of energy extraction, this research highlights their consistent personalized replies and other responses that rehearse arguments found prevalently in studies of the media coverage of fracking (O'Hara et al., 2013).

The above literature helps to extend the concern of this paper to explore the role of the media in shaping public understanding of, and debate on, the fracking issue. This literature is limited in scope nevertheless and as such we can look briefly elsewhere to fill the gaps in our knowledge of the present perceptions and the public discourse on fracking whilst bearing in mind the observed insights into the interactions of audiences with media reporting. More generally focused "public perception" studies reveal, we note, a similarity in the perception of the fracking issue among US, Canadian, and UK publics. Surveys show that there is a mixed awareness of the issue and, where instances of awareness are recorded, respondents demonstrate a distinct understanding of the economic benefits of fracking and the environmental and social risks associated with the fracking process (see Thomas et al., 2017 for a full review of the literature). Respondents connect hydraulic fracturing to a widely perceived need to maintain the general affordability of energy for households. They also introduce arguments about industry behavior and concerns over the governing of energy and climate change (Williams et al., 2015). Other UK based research recognizes a greater number of survey responses as connecting fracking to a perception of risk rather than to a perception of benefit, despite noting a general ambivalence to the fracking issue among respondents. In exploring the understandings that shape the recorded perceptions of respondents, including the levels of their basic knowledge of the fracking process (Choma et al., 2016), these studies introduce demographics, political views, and environmental values as playing an important role in informing respondents' perceptions (Whitmarsh et al., 2015).

Observing the publics use of online and social media provides equally important insights into the formation of public discourse on fracking. Studies discuss online material (the availability of the Gasland documentary on Youtube and others, for instance) as offering their audiences a sense of the "human face of fracking" (Jaspal et al., 2014b) and, in the process, as raising discussion on, and consciousness of, the issue among these audiences. Attending to online and social media provides, as Vasi et al. (2015) suggest, a clear sense of the discursive opportunities and the positions that people can adopt on the issue. In addition, these studies of online and social media help to question long held assumptions that mainstream media coverage works unaccompanied to shape public understandings of issues and, in turn, that measures of coverage can serve as "stand in" measures for public perceptions. As has been observed in the case of other environmental issues, the study of social media (twitter, facebook etc.) reveals a process of bottom up, rather than elite led (or top down) communication in addition to a variety of discussion on issues that differ from that commonly found in news reports (Arlt et al., 2018). Through social media, people connect directly with-unmediatedcommunication from stakeholders and as such they demonstrate globally informed and locally situated understandings of issues (Autry and Kelly, 2012). People also engage with other people in political debate online and use personal and micro blogs to articulate their views on issues (Haider, 2016). Yet, with many social media conversations centered around remediated traditional media stories on (fracking) issues (Binder A. R., 2012), we are reminded not to overlook the importance of media coverage in any view of the formation and the performance of public discourse on fracking.

\section{CONCLUSION}

This article has used insights from environmental communication research to explore the coverage of hydraulic fracturing in print media, social/online media, and blogs. As was expected, the communication of, and the emerging controversy over, this technique of energy extraction reveals insights into the developing politicization of the fracking issue. In some countries (e.g., the USA, UK, Poland) the national context, for example, is important to how fracking has become adopted and discussed as an issue in the mainstream media. A situation where fracking is incorporated as part of a national energy policy helps to explain the continuity in a proportion of the observed related media coverage. With journalists' attention attracted to the announcements that support the fracking process provided by the government, politicians and the representatives from the fracking industry, their subsequent news reporting reproduces these arguments about the benefits of the process for the economy and for national energy security. The reporting of fracking, as similar to that of other issues, includes evidence of the outcomes of the structural advantages and the public 
relations power of these institutions and industries over public discussion via the media (see Monbiot, 2007). Reproduced discussion of fracking activity as producing economic benefits (or potential benefits) for both national and local communities, occupies a privileged position in the overall reporting of hydraulic fracutring. Additionally, the evidence that exists on public perceptions shows that this generic framing resonates with the publics' concerns over "affordable energy" (Williams et al., 2015) and is successful in countering the communication of the risks associated with hydraulic fracturing activity at least in terms of sustaining an ambivalence toward the issue.

At the same time, problems have been observed in the processes of sustaining a pro-fracking discourse in media reporting over time. As yet, pro-fracking stakeholders have failed to sustain a discussion of the economic benefits of fracking across UK media coverage or to challenge environmental concerns with suitably "trustworthy messengers" (Bomberg, 2017). As a consequence, anti-fracking claims-making and campaigning now adopts a place among the general influences shaping media coverage. An outcome of these anti-fracking activities has been to shape fracking as a controversial issue and one now reported as a mainstream, and controversial, news story rather than a business story. Research has also shown the specific catalyst behind this move. At the center of the evolving controversy has been the spread through anti-fracking media, whether by documentary via Youtube or social media chatter (Vasi et al., 2015). Observing the mobilized protest activities that have emerged alongside online media and conversation and their interests in "local issues, local concerns and local needs" of affected citizens (Bomberg, 2017: p. 86), helps to reveal the interconnected influences that are informing the media reporting of environmental risks and the potential threats associated with the hydraulic fracturing process.

At this point, it would be pertinent also to acknowledge findings on the position of news organizations and journalistic practices in the process to select and to frame news stories on the fracking issue. While the contexts (geographic, political, economic) of journalists' news production environments and their related practices shape this reporting as has been demonstrated, so, it has been argued, will the potential growth of fracking as a locally contested issue. Turning our attention to future media coverage, we can acknowledge that introducing affected individuals or communities would change the dynamic in the narratives of media stories, moving these away from existing statements on the benefits, and/ or the risks, of the activity or conflicts between these positions and their stakeholders. Such a change however would not necessarily address the limitations observed in the local or in the national reporting generally. Drawing on the findings of perception research, we can suggest that this media reporting supports an understanding of stakeholder positions or an ambivalence to the issue among the public, though the demographics, the political views, and the values held by the public that Whitmarsh et al. (2015) and others note will be likely shaping their discussions including those based on media content (Binder A. R., 2012). Therefore, in contrast to this reporting, new kinds of reporting that adopt a more general stance on the issue would be needed to avoid delimiting the media discussion of fracking to selected stakeholder positions or those conflicts between them in this way. To put this into practice, journalists would be required to include greater information and content on fracking activity and, in turn it is suggested, to provide more context in their discussion of fracking activity for their audiences in terms of wider issues of cost, security and sustainability (Department of Energy and Climate Change, 2014). In addition, efforts to increase the amount of voices, issues and perspectives alongside the actual communicative space given over to discussions of the issue would avoid the reproduction of simple conflict-based stories or others that give license to commentators to express risk or benefit statements.

All of which whets the appetite for studying future developments. Given the increasing salience of the issue and the presence of environmental risks associated with it, of interest will be to study the activities of various stakeholders that will drive forward any future coverage. It will be important to observe the activities of governments, such as the UK government or others who are accepting of the technology, and their efforts made to either support the issue or to arbitrate between conflicting claims-makers in addition to how these scenarios will play out in news reporting and in other media. Of course, reporting will likely be linked to any growing presence of local criticism of, and protest on, hydraulic fracturing activity. If the fracking issue follows the course set by other locally protested environmental issues this development may have implications for the space given to pro-fracking discourses in future reporting. At the same time, it will be important to observe how any anti-fracking discourses develop and to analyse specifically the types of cultural resonances (Hansen, 1991) that they will mobilize [including appeals to notions of the interests and the concerns of "ordinary," decent, "little" people concerned to protect their (rural) environment, community and their way of life against the disruptive and potentially destructive impact of big business/industry seen to be insensitive to local environments and people, and only interested in economic and profit oriented goals]. For instance, will populist or romanticized ideologies be referenced as part of these concerns, including discourses on "taking back control" commonly found in the recent politics associated with Brexit in the UK and antiglobalization elsewhere?

In addition, future research will need to incorporate the positioning of broadcast media on the fracking issue in addition to the established insights gained on print and online/ social media and, as part of the process, widen the focus of its analysis from studying simple "crisis" moments or high-profile events (see Endres et al., 2016). As part of analyzing the everyday cumulative coverage of the issue (on traditional and online/social media), research will need to explore the differentiated practices that journalists use to both select and shape the reporting of fracking for different news outlets (traditional/online) and the wider "institutional" contexts (varying in terms of their geography, economics and political positioning) that inform story production over time. Similarly, more research will be required on the media audiences' understanding of, and positions taken in 
response to, the issue of fracking alongside their action(s) to remediate their thoughts and reactions via social media. Of direct relevance will be to examine the impact of the changing reporting, and/or changing circumstances, on the presently recorded-ambivalent-position they adopt on fracking activities. What is clear is that sustained research into the coverage of hydraulic fracturing, its production and its wider reception are required to move forward our understanding of the role of mediated public communication within national conversations on fracking, energy, and related environmental concerns.

\section{REFERENCES}

Anderson, A. (2014). Media, Environment and the Network Society. Houndmills: Palgrave Macmillan.

Anderson, A., and Marhadour, A. (2007). Slick PR? The media politics of the prestige oil spill. Sci. Commun. 29, 96-115. doi: 10.1177/1075547007305543

Ang, B. W., Choong,W. L., and Ng, T. S. (2015). Energy security: definitions, dimensions and indexes. Renewab. Sustainable Energy Rev. 42, 1077-1093. doi: 10.1016/j.rser.2014.10.064

Arlt, D., Rauchfleisch, A., and Schäfer, M. S. (2018). Between fragmentation and dialogue twitter communities and political debate about the Swiss "Nuclear Withdrawal Initiative". Environ. Commun. 12, 84-89. doi: 10.1080/17524032.2018.1430600

Autry, M. K., and Kelly, A. R. (2012). Merging duke energy and progress energy: online public discourse, post-fukushima reactions, and the absence of environmental communication. Environ. Commun. 6, 278-284. doi: 10.1080/17524032.2012.672444

Bennett, W. L. (1990). Toward a theory of press-state relations in the United States. J. Commun. 40, 103-125.

Benson, R. (2005). "Mapping field variation: Journalism in France and the United States," in Bourdieu and the Journalistic Field, eds R. Bensen and E. Neveu (Cambridge: Polity), 85-112.

Bigl, B. (2017). Fracking in the german press: securing energy supply on the eve of the 'Energiewende' - a quantitative framing-based analysis. Environ. Commun. 11, 231-247. doi: 10.1080/17524032.2016.1245207

Binder A. R. (2012). Fukushima: an initial look at functions and content of us twitter commentary about nuclear risk. Environ. Commun. J. Nat. Culture 6, 268-277. doi: 10.1080/17524032.2012.672442

Blair, B. D., Weible, C. M., Heikkila, T., and McCormack, L. (2015). Certainty and uncertainty in framing the risks and benefits of hydraulic fracturing in the Colorado news media. Risk Hazards Crisis Public Policy 6, 290-307. doi: $10.1002 /$ rhc 3.12086

Boczkowski, P. J., and Anderson,. C. W. (eds.) (2017). Remaking the News: Essays on the Future of Journalism Scholarship in the Digital Age. Cambridge, MA: The MIT Press.

Bolsen, T. (2011). The construction of news: Energy crises, advocacy messages, and frames toward conservation. Int. J. Press Polit. 16, 143-162. doi: $10.1177 / 1940161210392782$

Bomberg, E. (2017). Shale we drill? Discourse dynamics in UK fracking debates. J. Environ. Policy Plann. 19, 72-88. doi: 10.1080/1523908X.2015.10 53111

Boudet, H., Clarke, C., Bugden, D., Maibach, E., Roser-Renouf, C., and Leiserowitz, A. (2014). "Fracking" controversy and communication: using national survey data to understand public perceptions of hydraulic fracturing. Energy Policy 65, 57-67. doi: 10.1016/j.enpol.2013.10.017

Boyd, A. D. (2017). Examining community perceptions of energy systems development: the role of communication and sense of place. Environ. Commun. 11, 184-204. doi: 10.1080/17524032.2015.10 47886

Boykoff, M. T., and Boykoff, J. M. (2007). Climate change and journalistic norms: a case study of US mass-media coverage. Geoforum 38, 1190-1191. doi: 10.1016/j.geoforum.2007.01.008

\section{AUTHOR CONTRIBUTIONS}

JM led on initial drafting, and JM and $\mathrm{AH}$ then both wrote, reviewed, and edited this manuscript.

\section{ACKNOWLEDGMENTS}

The authors would like to thank The College of Arts Social Sciences and Humanities at the University of Leicester for their support in funding research into the media coverage of fracking from which this paper was developed.

Buttny, R., and Feldpausch-Parker, A. M. (2016). Communicating hydrofracking. Environ. Commun. 10, 289-291. doi: 10.1080/17524032.2016.1159278

Carvalho, A., and Burgess, J. (2005). Cultural circuits of climate change in the UK broadsheet newspapers. Risk Anal. 25, 1457-1469. doi: 10.1111/j.1539-6924.2005.00692.x

Chapman, G., Kumar, K., Fraser, C., and Gavor, I. (1997). Environmentalism and the Mass Media: The North South Divide. London: Roudledge.

Chen, S., and Gunster, S. (2016). "Ethereal Carbon": legitimizing liquefied natural gas in British Columbia. Environ. Commun. 10, 305-321. doi: 10.1080/17524032.2015.1133435

Choi, J. (2012). A content analysis of BP's press releases dealing with crisis. Public Relat. Rev. 38, 422- 429. doi: 10.1016/j.pubrev.2012.03.003

Choma, B. L., Hanoch, Y., and Currie, S. (2016). Attitudes toward hydraulic fracturing: the opposing forces of political conservativism and basic knowledge of fracking. Glob. Environ. Change 38, 108-117. doi: 10.1016/j.gloenvcha.2016.03.004

Cotton, M. (2015). Stakeholder perspectives on shale gas fracking: A Qmethod study of environmental discourses. Environ. Plann. 47, 1944-1962. doi: 10.1177/0308518X15597134

Cotton, M., Rattle, I., and Van Alstine, J. (2014). Shale gas policy in the United Kingdom: an argumentative discourse analysis. Energy Policy 73, 427-438. doi: 10.1016/j.enpol.2014.05.031

Cox, R. (2007). Nature's "crisis disciplines": does environmental communication have an ethical duty? Environ. Commun. 1, 5-20. doi: 10.1080/17524030701333948

Cox, R. (2010). Environmental Communication and the Public Sphere, 2nd Edn. London: Sage.

Cozen, B., Endres, D., Peterson, T. R., Horton, C., and Barnett, J. T. (2017). Energy communication: theory and praxis towards a sustainable energy future. Environ. Commun. 12, 289-294. doi: 10.1080/17524032.2017.13 98176

Culley, M. R., Ogley-Oliver, E., Carton, A. D., and Street, J. C. (2010). Media framing of proposed nuclear reactors: an analysis of print media. J. Community Appl. Soc. Psychol. 20, 497-512. doi: 10.1002/casp.1056

Curtin, P. A., and Rhodenbaugh, E. (2001). Building the news media agenda on the environment: a comparison of public relations and journalistic sources. Public Relat. Rev. 27, 179-195. doi: 10.1016/S0363-8111(01) 00079-0

Daley, P., and O'Neill, D. (1991). Sad is too mild a word: press coverage of the Exxon Valdez oil spill. J. Commun. 41, 42-57. doi: 10.1111/j.1460-2466.1991.tb02330.x

Davidsen, C., and Graham, D. (2014). Newspaper reporting on climate change, green energy and carbon reduction strategies across Canada 1999-2009. Am. Rev. Can. Stud. 44, 151-168. doi: 10.1080/02722011.2014.9 14047

DeLuca, K. M. (2009). Greenpeace international media analyst reflects on communicating climate change. Environ. Commun. 3, 263-269. doi: 10.1080/17524030902972734

Department of Energy and Climate Change (2014). Public Engagement With Shale Gas And Oil: A Report On Findings From Public Dialogue Workshops. Available online at: https://www.gov.uk/government/publications/public-engagementwith-shale-gas-and-oil. 
Djerf-Pierre, M., Cokley, J., and Kuchel, L. J. (2015). Framing renewable energy: a comparative study of newspapers in australia and sweden. Environ. Commun. 10, 634-655. doi: 10.1080/17524032.2015.1056542

Endres, D. E., Cozen, B., Trey Barnett, J., O’Byrne, M., and Rai Peterson, T. (2016). Communicating energy in a climate (of) crisis. Ann. Int. Commun. Assoc. 40, 419-447. doi: 10.1080/23808985.2015.11735267

Evensen, D. T., Clarke, C. E., and Stedman, R. C. (2014). A new york or pennsylvania state of mind: social representations in newspaper coverage of gas development in the Marcellus Shale. J. Environ. Stud. Sci. 4, 65-77. doi: 10.1007/s13412-013-0153-9

Feldpausch-Parker, A. M., and Peterson, T. R. (2014). Communicating the science behind carbon sequestration: a case study of US department of energy and regional partnership websites. Environ. Commun. 9, 326-345. doi: $10.1080 / 17524032.2014 .955039$

Finewood, M. H., and Stroup, L. J. (2012). Fracking and neoliberalization of the hydro-social cycle in Pennsylvania's Marcellus Shale. J. Contemp. Water Res. Educ. 147, 72-79. doi: 10.1111/j.1936-704X.2012.03104.x

Flynn, J., Peters,E., Mertz, C. K., and Slovid, P. (1988). Risk, media, and stigma at rocky flats. Risk Anal. 18, 715-727. doi: 10.1111/j.1539-6924.1998.tb01115.x

Fuller, S., and McCauley, D. (2016). Framing energy justice: perspectives from activism and advocacy. Energy Res.Soc. Sci. 11, 1-8. doi: 10.1016/j.erss.2015.08.004

Gamson, W. A. (1992). Talking Politics. Cambridge: Cambridge University Press.

Gamson, W. A., and Modigliani, A. (1989). Media discourse and public opinion on nuclear power: a constructionist approach. Am. J. Soc. 95, 1-37. doi: $10.1086 / 229213$

Gurevitch, M., Levy, M., and Roeh, I. (1991). "The global newsroom: convergences and diversities in the globalisation of television news," in Communications and Citizenship: Journalism and the Public Sphere in the New Media Age, eds P. Dahlgren, and C. Sparks (London: Routledge), 195-216.

Habib, S., and Hinojosa, M. S. (2016). Representation of fracking in mainstream American newspapers. Environ. Prac. 18, 83-93. doi: $10.1017 /$ S1466046616000089

Haider, J. (2016). The shaping of environmental information in social media: affordances and technologies of self-control. Environ. Commun. 10, 473-491. doi: 10.1080/17524032.2014.993416

Hallin, D. (1985). The 'Uncensored War': The Media and Vietnam. Oxford: Oxford University Press.

Hannigan, J. (2014). Environmental Sociology, 3rd Edn. London: Routledge.

Hansen, A. (1991). Media and the social construction of the environment. Media Culture Soc. 13, 443-458. doi: 10.1177/016344391013004002

Hansen, A. (2000). "Claims-making and framing in British newspaper coverage of the 'brent spar' controversy," in Environmental Risks and the Media, eds S. Allan, B. Adam, and C. Carter (London: Routledge), 55-72.

Hansen, A. (2009). "Science, communication and media," in Investigating Science Communication in the Information Age: Implications for public Engagement and Popular Media, eds R. Holliman, E. Whitelegg, E. Scanlon, S. Smidt, and J. Thomas (Milton Keynes: Oxford University Press and The Open University), 105-127.

Hansen, A. (2010). Environment, Media and Communication. London: Routledge.

Hansen, A. (2011). Communication, media and environment: towards reconnecting research on the production, content and social implications of environmental communication. Int. Commun. Gazette 73, 7-25. doi: $10.1177 / 1748048510386739$

Hansen, A., and Cox, R. (eds.) (2015). The Routledge Handbook of Environment and Communication. London: Routledge.

Hedding, K. J. (2017). Sources and framing of fracking: a content analysis of newspaper coverage in North Carolina, New York, and Pennsylvania. Environ. Commun. 11, 370-385. doi: 10.1080/17524032.2016.1269819

Hopke, J. E. (2016). Translocal anti-fracking activism: an exploration of network structure and tie content. Environ. Commun. 10, 380-394, doi: $10.1080 / 17524032.2016 .1147474$

Hudgins, A., and Poole, A. (2014). Framing fracking: private property, common resources, and regimes of governance. J. Polit. Ecol. 21, 222-348. doi: $10.2458 / \mathrm{v} 21 \mathrm{i} 1.21138$

Jaspal, R., and Nerlich, B. (2014). Fracking in the UK press: threat dynamics in an unfolding debate. Public Understand. Sci. 23, 348-363. doi: $10.1177 / 0963662513498835$
Jaspal, R., Nerlich, B., and Lemancyzk, S. (2014a). Fracking in the Polish press: geopolitics and national identity. Energy Policy 74, 253-261. doi: 10.1016/j.enpol.2014.09.007

Jaspal, R., Turner, A., and Nerlich, B. (2014b). Fracking on youtube: exploring risks, benefits, and human values. Environ. Values 23, 501-505. doi: 10.3197/096327114X13947900181473

Johnstone, B., and Mando, J. (2015). Proximity and journalistic practice in environmental discourse: Experiencing 'job blackmail' in the news. Discour. Commun. 9, 81-101. doi: 10.1177/1750481314555266

Kitzinger, J. (1998). "Media impact on public beliefs about AIDS," in The Circuit of Mass Communication, eds D. Miller, J. Kitzinger, K. Williams, and P. Beharrell (London: Sage), 167-191. doi: 10.4135/9781446279984.n8

Krause, A., and Bucy, E. P. (2018). Interpreting images of fracking: how visual frames and standing attitudes shape perceptions of environmental risk and economic benefit. Environ. Commun. 12, 322-334. doi: 10.1080/17524032.2017.1412996

Kristiansen, S. (2017). Characteristics of the mass media's coverage of nuclear energy and its risk: a literature review. Soc. Compass 11, 1-10. doi: $10.1111 /$ soc 4.12490

Livingstone, S. (2009). On the mediation of everything: ICA presidential address 2008. J. Commun. 59, 1-18. doi: 10.1111/j.1460-2466.2008.01401.x

Lowe, P., and Morrison, D. (1984). Bad news or good news: environmental politics and the mass media. Sociol. Rev. 32, 75-90. doi: 10.1111/j.1467-954X.1984.tb00780.x

Maeseele, P. (2017). "The depoliticization of environmental discourse and politics," in COCE Annual Conference - Democracy, Borders and Public/Political Engagement: Challenges for Environmental Communication (Leicester: University of Leicester).

Maeseele, P., Deneckere, K., Panis, K., and Paulussen, S. (2015). The energy question in the Belgian daily press during 2010: the role of region, newspaper type and newspaper section. J. Sci. Commun. 14, 1-17. doi: $10.22323 / 2.14010203$

Matthews, J. (2016). Maintaining a politicized climate of opinion? Examining how political framing and journalistic logic combine to shape speaking opportunities in UK elite newspaper reporting of climate change. Public Understand. Sci. 26, 467-480. doi: 10.1177/0963662515599909

Matthews, J., and Brown, A. (2012). Negatively shaping the asylum agenda? The representational strategy and impact of a tabloid news campaign. J. Crit. Theor. Prac. 13, 802-817. doi: $10.1177 \% 2$ F1464884911431386

Matthews, J., and Cottle, S. (2012). Television news ecology in the United Kingdom: a study of communicative architecture, its production and meanings. Telev. N. Media 13, 103-123. doi: 10.1177/1527476411403630

Matthews, J., and Hansen, A. (2016). "Fracturing debate? A study of national (UK) press coverage of 'fracking,"' in IAMCR Annual Conference, Memory, Commemoration and Communication: Looking Back, Looking Forward (Leicester: University of Leicester).

Matz, J., and Renfrew, D. (2015). Selling "fracking": energy in depth and the marcellus shale. Environ. Commun. 9, 288-306. doi: $10.1080 / 17524032.2014 .929157$

Mazur, A. (2013). Energy and Electricity in Industrial Nations: The Sociology and Technology of Energy. London; New York, NY: Routledge.

Mazur, A. (2016). How did the fracking controversy emerge in the period 20102012? Public Understand. Sci. 25, 207-222. doi: 10.1177/0963662514545311

Mercado,T., Álvarez, A., and Herranz, J. M. (2014). The fracking debate in the media: the role of citizen platforms as sources of information. J. Commun. Stud. $7,45-62$.

Metze, T. (2014). Fracking the debate: frame shifts and boundary work in dutch decision making on shale gas. J. Environ. Policy Plann. 19, 35-52. doi: 10.1080/1523908X.2014.941462

Metze, T., and Dodge, J. (2016). Dynamic discourse coalitions on hydrofracking in Europe and the United States. Environ. Commun. 10, 365-379. doi: $10.1080 / 17524032.2015 .1133437$

Monbiot, G. (2007). Heat: How to Stop the Planet from Burning. Cambridge, MA: South End Press.

Neil, J., Schweickart, T., Zhang, T., Lukito, J., Young-Kim, J., Golan, G., et al. (2018). The dash for gas. J. Stud. 19, 182-208. doi: 10.1080/1461670X.2016.1181528

Neslen, A. (2016). The rise and fall of Fracking in Europe. Guardian. 29/9/16. 
Nisbet, M. (ed.) (2018). The Oxford Encyclopedia of Climate Change Communication. Oxford: Oxford University Press. doi: 10.1093/acref/9780190498986.001.0001

O’Hara, S., Humphrey, M., Jaspal, J., Nerlich, B., and Poberezhskaya, M. (2013). Public Perception of Scale Gas Extraction in the Uk: How People's Views Are Changing. Nottingham: University of Nottingham.

Olive, A. (2016). What is the fracking story in Canada? Can. Geogr. 60, 32-45. doi: $10.1111 /$ cag. 12257

Olive, A., and Delshad, A. B. (2017). Fracking and framing: a comparative analysis of media coverage of hydraulic fracturing in Canadian and US newspapers. Environ. Commun. J. Nat. Culture 11, 784-799. doi: 10.1080/17524032.2016.1275734

Pepermans, Y., and Maeseele, P. (2016). The politicization of climate change: problem or solution? Wiley Interdisciplinary Rev. 7, 478-485. doi: $10.1002 /$ wcc. 405

Pezzullo, P. C., and Cox, R. (2018). Environmental Communication and the Public Sphere, 5th Edn. London: Sage.

Philo, G., and Happer, C. (2013). Communicating Climate Change and Energy Security: New Methods in Understanding Audiences. London: Routledge. doi: $10.4324 / 9780203380956$

Pralle, S., and Boscarino,. J. (2011). Framing trade-offs: the politics of nuclear power and wind energy in the age of global climate change. Rev. Policy Res. 28, 323-346. doi: 10.1111/j.1541-1338.2011.00500.x

Rich, J. L. (2016). Drilling is just the beginning: romanticizing rust belt identities in the campaign for shale gas. Environ. Commun. 10, 292-304. doi: 10.1080/17524032.2016.1149085

Rootes, C. (2013). From local conflict to national issue: when and how environmental campaigns succeed in transcending the local. Environ. Politics 22, 95-114. doi: 10.1080/09644016.2013.755791

Ross, K., and Nightingale, V. (2003). Media and Audiences: New Perspectives. Maidenhead: OU Press.

Schirrmeister, M. (2014). Controversial futures-discourse analysis on utilizing the "fracking" technology in Germany. Eur. J. Futures Res. 2, 1-9. doi: 10.1007/s40309-014-0038-5

Schmidt, A., Ivanova, A., and Schäfer, M. S. (2013). Media attention for climate change around the world a comparative analysis of newspaper coverage in 27 countries. Glob. Environ. Change 23, 1233-1248. doi: 10.1016/j.gloenvcha.2013.07.020

Schneider, J., Schwarze, S., Bsumek, P. K., and Peeples, J. (2016). Under Pressure: Coal Industry Rhetoric and Neoliberalism. London: Palgrave.

Shehata, A., and Hopmann, D. N. (2012). Framing climate change: a study of US and Swedish press coverage of global warming. J. Stud. 13, 175-192. doi: 10.1080/1461670X.2011.646396

Sjölander, A. E., and Jönsson, A. M. (2012). "Contested ethanol dreams- public particpation in environmetal news," in Citizen Voices: Performing Public Participation in Science and Environmetal Communication, eds L. Phillips., A. Carvalho, and J. Doyle (Bristol: Intellect), 47-72.

Sneegas, G. (2016). Media representations of hydraulic fracturing and agriculture: a New York case study. Extractive Ind. Soc. Intl. J. 3, 95-102. doi: $10.1016 /$ j.exis.2015.11.011

Steger, T., and Drehobl, A. (2018). The anti-fracking movement in Ireland: perspectives from the media and activists. Environ. Commun. 12, 344-356. doi: 10.1080/17524032.2017.1392333
Stephens, J. C., Rand, G. M., and Melnick, L. L. (2009). Wind energy in US media: a comparative state-level analysis of a critical climate change mitigation technology. Environ. Commun. 3, 168-190. doi: 10.1080/17524030902916640

Takach, G. (2016). Sands of Space and Time: Scripting Environmental Communication, Oil and Democracy. London: Palgrave Macmillan.

Teräväinen, T. (2014). Representations of energy policy and technology in British and Finnish newspaper media: a comparative perspective. Public Understand. Sci. 23, 299-315. doi: 10.1177/0963662511409122

Thomas, M., Pidgeon, N., Evensen, D., Partridge, T., Hasell, A., Enders, C., et al. (2017). Public perceptions of hydraulic fracturing for shale gas and oil in the United States and Canada. Wiley Interdiscipl. Rev. Climate Change 8:e450. doi: $10.1002 /$ wcc. 450

Tollefson, J. W. (2014). The discursive reproduction of technoscience and Japanese national identity in The Daily Yomiuri coverage of the Fukushima nuclear disaster. Discour. Commun. 8, 299-317. doi: 10.1177/17504813135 10817

Vasi, I. B., Walker, E. T., Johnson, J. S., Tan, H. F. (2015). "No Fracking Way!" documentary film, discursive opportunity, and local opposition against hydraulic fracturing in the United States, 2010 to 2013. Am. Soc. Rev. 80, 934-959. doi: $10.1177 / 0003122415598534$

Wakefield, S. E. L., and Elliott, S. L. (2003). Constructing the news: the role of local newspapers in environmental risk communication. Prof. Geogr. 55, 216-226. doi: 10.1111/0033-0124.5502009

Wang, Y., Li, N., and Li, J. (2014). Media coverage and government policy of nuclear power in the People's Republic of China. Prog. Nuclear Energy 77, 214-223. doi: 10.1016/j.pnucene.2014.07.007

Whitmarsh, L. (2015). "Analysing public perceptions, understanding and images of environmental change," in The Routledge Handbook of Environment and Communication, eds A. Hansen, and R. Cox (London; New York, NY: Routledge), 339-353.

Whitmarsh, L., Nash, N., Upham, P., Lloyd, A., Verdon, J. P., and Kendall, M. (2015). UK public perceptions of shale gas hydraulic fracturing: the role of audience, message and contextual factors on risk perceptions and policy support. Appl. Energy 1, 419-430. doi: 10.1016/j.apenergy.2015.09.004

Wiggins, O., and Hicks, J. (2017). Maryland Senate Gives Final Approval to Fracking Ban. Washington Post 28.3.2017.

Williams, L., Macnaghten, Davis, R., and Curtis, S. (2015). Framing 'fracking': exploring public perceptions of hydraulic fracturing in the United Kingdom. Public Understand. Sci. 26, 89-104. doi: 10.1177/09636625155 95159

Wright, W., and Reid, T. (2011). Green dreams or pipe dreams? Media framing of the U.S. biofuels movement. Biomass Bioenergy 33, 1390-1399. doi: 10.1016/j.biombioe.2010.07.020

Conflict of Interest Statement: The authors declare that the research was conducted in the absence of any commercial or financial relationships that could be construed as a potential conflict of interest.

Copyright $\odot 2018$ Matthews and Hansen. This is an open-access article distributed under the terms of the Creative Commons Attribution License (CC BY). The use, distribution or reproduction in other forums is permitted, provided the original author(s) and the copyright owner(s) are credited and that the original publication in this journal is cited, in accordance with accepted academic practice. No use, distribution or reproduction is permitted which does not comply with these terms. 